УДК 334.72:364

A. A. Сибирка,

к. е. н., в. о. доцента кафедри економіки підприємства та управління персоналом,

Чернівещький начіональний університет імені Юрія Федьковича

ORCID ID: 0000-0001-7455-6544

O. M. Amumpiєba,

студентка, Чернівецький начіональний університет імені Юрія Федьковича

ORCID ID: 0000-0002-8253-2486

K. В. Сироїжко,

студентка, Чернівещький начіональний університет імені Юрія Федьковича

ORCID ID: 0000-0002-3090-2844

DOI: $10.32702 / 2306-6814.2019 .22 .47$

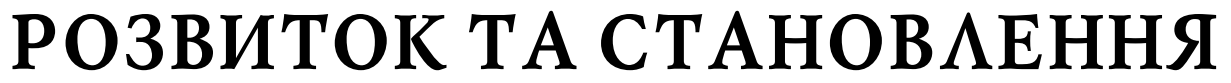 СОЦІААЬНОГО ПІАПРИЕМНИЦТВА ТА СОЦІА $\Lambda$ ВНОÏ ВІАПОВІАА $\Lambda$ ВНОСТI БIЗHECУ
}

\author{
L. Sybyrka, \\ $\mathrm{PhD}$ in Economics, Acting Associate professor of the Department of Enterprise Economics and Human Resource \\ Management, Yuriy Fedkovych Chernivtsi National University \\ O. Dmytriieva, \\ Master student, Yuriy Fedkovych Chernivtsi National University \\ K. Syroizhko, \\ Master student, Yuriy Fedkovych Chernivtsi National University
}

\section{DEVELOPMENT AND INCIPIENCE OF SOCIAL ENTREPRENEURSHIP AND CORPORATE SOCIAL RESPONSIBILITY}

Устатті проаналізовано різноманітні підходи вчених до вивчення соціальної відповідальності бізнесу як необхідної передумови ії ефективного впровадження у практику діяльності підприємницьких структур. Зазначено, що постійно проводяться нові теоретичні розробки та концептуальні положення різних характерів. Досліджено сутнісні характеристики та особливості соціального підприємництва та соціальної відповідальності бізнесу, які впливають на процес реалізації основних напрямів розвитку соціально відповідального бізнесу як у країнах світу, так $i$ в Україні. Розглянуто цілі сталого розвитку України і шляхи їх досягнення. Проаналізовано основні етапи розвитку та становлення соціально відповідального бізнесу в Україні та в світі загалом, а також діяльність вітчизняних підприємств у цій сфері і початок її зародження в Україні.

The article analyzes various approaches of scientists to the study of social responsibility of business as a necessary prerequisite for its effective implementation in the practice of business structures. The evolution of concepts that are scientifically grounded is considered. The main factors that influenced the development of social entrepreneurship and social responsibility of business in Ukraine are analyzed. It is stated that new theoretical developments and conceptual provisions of various characters are constantly being carried out. The essential characteristics and features of social entrepreneurship and social responsibility of business that influence the process of realization of the main directions of development of socially responsible business both in the countries of the world and in Ukraine are investigated. The basic international standards of social entrepreneurship and social responsibility of business are defined, which define the principles and standards of social 
responsibility of business, but which are only certain ethical norms, not legal rules of regulation. Basic documents that include standards of corporate social responsibility are outlined, including: UN Global Compact, Greenpop Book on Corporate Social Responsibility, International Standard 180 26000, OECD Guidelines on Transnational Companies. The importance of social entrepreneurship and social responsibility for the development of the country and society is highlighted. The goals of sustainable development of Ukraine and ways of their achievement are considered. The basic stages of development and incipience of socially responsible business in Ukraine and in the world as a whole, as well as the activity of domestic enterprises in this field and the beginning of its birth in Ukraine are analyzed. The main landmarks of social entrepreneurship, which were most in demand during $2014-$ 2017, are formed. It is determined that corporate social responsibility is not just a socio-economic and managerial category, but also a philosophical and moral-ethical one that everyone can view from a different perspective.

Ключові слова: соціальне підприємництво, соціальна Відповідальність бізнесу, міжнародні ініціативи, Глобальний Договір ООН, Цілі сталого розВитку України.

Keywords: social entrepreneurship, corporate social responsibility, international initiatives, United Nations Global Compact, Sustainable Development Goals of Ukraine.

\section{ПОСТАНОВКА ПРОБАЕМИ}

Формування ефективної ринкової економічної моделі зумовлює нову сутність взаємодії суспільства і бізнесу. Одним із найголовніших її складників є соціальна відповідальність ділового співтовариства, компаній і представників бізнесу, яка перетворюється у додатковий засіб підвищення іміджу підприємницьких структур.

Досвід економічно розвинутих держав свідчить, що від ефективності фоормвання системи партнерських відносин приватного підприємництва, влади і громадянського суспільства в соціальній ссрері багато в чому залежать якість життя населення і соціальна стабільність у країні. Процес глобалізації, притаманний сучасному бізнесу, визначив формування стандартів соціальної відповідальності та етичних правил підприємництва, започаткованих міжнародними організаціями.

Підприємницькі бізнес-структури, які працюють в Україні, протягом останніх років усе більшою мірою рухаються шляхом розвитку корпоративної прозорості, соціальної відповідальності та ефективності. Концепція корпоративного соціального бізнесу сприяє зростанню капіталізації та зміцненню стійкості бізнесу, виступає засобом соціального позиціонування і формування іміджу сучасної соціально орієнтованої компанії.

Попри значну кількість наукової літератури з питань соціального підприємництва та соціальної відповідальності бізнесу, потребують теоретичного обгрунтування питання комплексного підходу до розуміння її сутності, а також методичні та практичні аспекти впровадження та реалізації принципів ведення соціально відповідального бізнесу. Все це визначає актуальність подальшого розроблення та вдосконалення методології теоретичних досліджень соціальної відповідальності з урахуванням вітчизняної специфріки ведення бізнесу.

\section{АНА $\Lambda$ I3 ОСТАНHIX АОС $\Lambda$ ІАЖЕНЬ I ПУБАІКАЦІЙ}

Західні вчені Г. Боуен, Д. Вайс, Д. Віндзор, Т. Доналдсон, Р. Каплан, А. Керол, Т. Левітт, Д. Нортон, М. Фрідман у своїх фундаментальних працях розробили основи класичного розуміння корпоративної соціаль- ної відповідальності. Значний внесок у розробку теорії соціальної відповідальності підприємств зробили українські вчені: Д. Баюра, О. Березіна, О. Буян, В. Воробей, О. Ворона, Л. Грицина, В. Євтушенко, І. Журовська, В. Карагод, А. Колот, Р. Курінько, О. Черних та ін. У їхніх працях проаналізовано зарубіжний досвід упровадження соціального підприємництва, здійснено теоретичний аналіз закономірностей і тенденцій її функціонування, показано процес розширення практик соціально відповідального бізнесу в Україні.

\section{META CTATTI}

Метою статті $€$ характеристика етапів становлення та розвитку соціального підприємництва та соціально відповідального бізнесу, окреслення шляхів імплементації концепції соціальної відповідальності бізнесу в стратегію розвитку українських підприємств з урахуванням міжнародних ініціатив.

\section{ВИКААА ОСНОВНОГО \\ MATEPIA $\Lambda$ У}

Соціальна відповідальність бізнесу є підсистемою соціальної відповідальності загальної системи суспільної взаємодії, а також засобом гарантування та охорони суспільних відносин, які встановлюються певними суб'єктами та гарантуються певними засобами з метою дотримання поваги до прав людини, є проявом культури суспільства, реалізації його суспільних інтересів і регламентується соціальними нормами, контролюється санкціями. Цей феномен уособлює елементи надбудови суспільства, що залежать від рівня розвитку економічних, політичних та суспільних відносин; розвивається та трансформується разом із суспільними відносинами; $€$ добровільною ініціативою організацій (компаній) щодо дотримання етичних норм у сфрері соціальної взаємодії та прийняття на себе відповідальності за вплив на навколишнє середовище, партнерів, споживачів, працівників, громади тощо.

Світова практика свідчить, що концепція соціально відповідального бізнесу успішно розвивається і перебуває у процесі постійних змін та вдосконалень. 
ЕКОНОМИНА НАУКА

Реакцією на потребу розбудови успішних прикладних систем соціально відповідальної діяльності стала поява в цій царині цілої низки концепцій, які містять результати наукового опрацювання питань соціальної відповідальності бізнес-структур (табл. 1).

Історично склалося кілька підходів до визначення поняття соціальної відповідальності бізнесу, зокрема: фрілософрський, соціально-економічний та управлінський. Водночас аналіз літературних джерел свідчить, що світова економічна думка постійно проводить нові теоретичні розробки та концептуальні положення, передусім управлінського та соціальноекономічного характеру.

Відповідно до управлінського підходу, за визначенням міжнародного стандарту 15026000 , соціальна відповідальність бізнесу - це відповідальність організації за вплив своїх рішень та діяльності (а саме продукцію і послуги) на суспільство і навколишнє середовище, що реалізується через прозору і етичну поведінку, відповідає сталому розвитку та добробуту суспільству, враховує очікування зацікавлених сторін, поширена в усій організації і не суперечить відповідному законодавству і міжнародним нормам поведінки [9, с. 68].

Згідно з 15026000 соціальна відповідальність компанії включає такі компоненти, як захист прав людини, навколишнього природного середовища, безпеку праці, права споживачів та розвиток місцевих громад, а також організаційне управління та етику бізнесу. Тобто у новому керівництві враховані усі принципи, які зазначені у Глобальній ініціативі ООН (документи, до якого приєдналося 6 тисяч компаній та організацій, серед яких 130 українських).

Міжнародний стандарт С5В / КСВ - 2008, введений в дію спільним рішенням Української асоціації якості, Міжнародної асоціації менеджерів і аудиторів якості, визначає, що "...соціальна відповідальність зобов'язання організації, що враховують прийняту нею відповідальність за вирішення соціальних проблем свого персоналу, місцевого населення і суспільства в цілому"

У стратегії "Європа-2020", як і в більшості програмних документів Європейського Союзу, поняття "соціальна відповідальність бізнесу", визначається як добровільні зобов'язання підприємницьких структур, що виходять за межі чинних законодавчих норм, нести відповідальність за результати своєї діяльності не лише в економічній, але й у соціальній та екологічній сфрерах. Ця відповідальність поширюється на значне коло зацікавлених осіб - власників, працівників компанії, місцеве населення і суспільство загалом [11].

За С.В. Перегудовим, соціальна відповідальність бізнесу виходить за рамки встановлених законом норм і передбачає діяльність, спрямовану на задоволення суспільних потреб [8, с. 24].

Абрамов Р.Н. зазначає, що соціальна відповідальність бізнесу - частина корпоративної відповідальності, що представляє область діяльності компанії, пов'язаними з добровільно взятими на себе соціальними зобов'язаннями щодо зацікавлених груп і суспільства загалом [1, с. 328].

Гончаров С.Ф. визначає соціальну відповідальність бізнесу як систему взаємовідносин між працівником,
Таблиця 1. Еволюція концепцій соціальної відповідальності

\begin{tabular}{|c|c|c|}
\hline Назва концепції & Представник & Характеристика \\
\hline 1 & 2 & 3 \\
\hline $\begin{array}{l}\text { Базова концепція } \\
\text { корпоративної } \\
\text { соціальної } \\
\text { зідповідальності }\end{array}$ & $\begin{array}{l}\text { А. Керролл } \\
\text { [13] }\end{array}$ & $\begin{array}{l}\text { Корпоративна соціальна } \\
\text { відповідальність - відповідність } \\
\text { економічним, правовим, етичним } \\
\text { і дискреційним очікуванням, що } \\
\text { їх покладає суспільство на } \\
\text { організації в даний період часу }\end{array}$ \\
\hline $\begin{array}{l}\text { Концепція } \\
\text { корпоративної } \\
\text { соціальної } \\
\text { сприйнятливості }\end{array}$ & $\begin{array}{l}\text { В. Фредерік } \\
{[14]}\end{array}$ & $\begin{array}{l}\text { Ідея корпоративної соціальної } \\
\text { сприйнятливості є } \\
\text { управлінською за своїм } \\
\text { характером і підходами, а її } \\
\text { захисники приділяють основну } \\
\text { увагу менеджменту відносин } \\
\text { компаній із суспільством }\end{array}$ \\
\hline $\begin{array}{l}\text { Концепція } \\
\text { корпоративної } \\
\text { соціальної діяльності }\end{array}$ & $\begin{array}{l}\text { Д. Свансон } \\
\text { [15] }\end{array}$ & $\begin{array}{l}\text { Корпоративна соціальна } \\
\text { діяльність залежить передусім } \\
\text { від персональних цінностей осіб, } \\
\text { які приймають рішення в } \\
\text { організації. Водночас } \\
\text { корпоративна соціальна } \\
\text { сприйнятливість, як елемент } \\
\text { комплексної моделі } \\
\text { корпоративної соціальної } \\
\text { діяльності, розглядається в } \\
\text { широкому контексті }\end{array}$ \\
\hline $\begin{array}{l}\text { Концепція } \\
\text { консолідованої } \\
\text { (спільної, } \\
\text { комунітарної) } \\
\text { соціальної } \\
\text { відповідальності }\end{array}$ & $\begin{array}{l}\text { А.М. Колот } \\
\text { [6] }\end{array}$ & $\begin{array}{l}\text { Консолідована (спільна) } \\
\text { соціальна відповідальність } \\
\text { заперечує домінування } \\
\text { індивідуального і колективного } \\
\text { егоїзму, натомість передбачає } \\
\text { рівноцінну відповідальність усіх } \\
\text { соціальних партнерів }\end{array}$ \\
\hline
\end{tabular}

роботодавцем і державою, спрямована на вдосконалення соціально-трудових відносин, підтримку соціальної стабільності в трудовому колективі і навколишньому співтоваристві, розвиток соціальної і природоохоронної діяльності на національному та міжнародному рівнях [3, с. 5].

Данилова О.В. зазначає, що соціальна відповідальність бізнесу - це система відносин, що відтворює діяльність, орієнтовану на досягнення економічного і соціального ефректу в процесі суспільного відтворення; створення стабільного економічного середовища; інтелектуалізацію основного ресурсу національної економіки - це людського капіталу [4, с. 7].

Проведений нами аналіз підходів до розуміння явища соціально відповідальності бізнесу свідчить про наявність суттєвих відмінностей у напрямах соціальної активності бізнесових структур. Це можна пояснити різницею соціально-економічного розвитку і якістю інституціонального середовища, специфрікою ділового і соціального середовища, в якому функціонує або 3 яким стикається та чи інша компанія, різноманіттям соціальних викликів, які постають перед організаціями, відмінностями в завданнях щодо підвищення конкурентоспроможності та, врешті-решт, відмінностями менталітету топ-менеджменту.

Що ж до ролі соціальної відповідальності бізнесу, можна з упевненістю сказати, що на сьогодні соціальна відповідальність бізнесу розглядається як активна соціальна позиція компанії, що полягає в гармонійному співіснуванні, взаємодії та постійному діалозі із суспільством та виявляється в участі компанії у вирішенні найгостріших соціальних проблем громади та суспільства. 
Виходячи на світову арену, українські підприємства мають орієнтуватися на міжнародні стандарти соціального підприємництва та соціальної відповідальност бізнесу. У світовій практиці сьогодні існує декілька ініціатив, що визначають принципи та стандарти соціальної відповідальності бізнесу, водночас необхідно підкреслити, що ці принципи і стандарти не є юридичними нормами регулювання поведінки бізнесу, ає лише етичними нормами, яких має дотримуватися бізнес на добровільних началах.

Однією з перших таких ініціатив став Глобальний договір $\mathrm{OOH}$, що був розпочатий Генеральним Секретарем ООН Кофрі Аннаном: на Всесвітньому економічному конгресі в 1999 році лідери бізнесу були запрошені приєднатися до глобальної ініціативи з метою партнерства та підтримки принципів у сфері прав людини, стандартів праці, охорони навколишнього середовища, протидії корупції. Глобальний договір містить десять пунктів - орієнтирів діяльності бізнесу, які мають стати кодексом поведінки для всіх компаній, що приєднуються до ініціативи. Зокрема серед пунктів зобов'язання бізнесу протидіяти корупції, підтримувати і поважати захист прав людини, сприяти розвитку і розповсюдженню екологічно безпечних технологій, виступати проти всіх форм примусової праці, дитячої праці, не допускати расової дискримінації серед співробітників. Україна приєдналася до Глобального договору в 2006 році, а в 2007 році ініціативу ООН підтримали 85 українських компаній. Натомість уже в 2013 році Глобальний договір повідомив про виключення 4 українських компаній із лав ініціативи. Причина - відмова компаній звітувати про прогрес протягом двох років поспіль. Станом на 16 липня 2016 року від України зареєстровано 266 учасників Глобального договору $\mathrm{OOH}$.

Прийнятий в 2010 році міжнародний стандарт 18026000 розкриває сутність соціальної відповідальності, надає бізнесу рекомендації стосовно практик принципів соціального підприємництва. Документ було розроблено за участю експертів з різних країн, серед яких були представники споживачів, робітників, держави, промисловості, недержавних організацій. Українська сторона також брала участь у розробці цього міжнародного стандарту [2, с. 46].

Ще один документ, який містить стандарти соціальної відповідальності бізнесу - це "Керівні Принципи ОЕСР щодо транснаціональних компаній". Принципи ОЕСР - це зібрання стандартів з різних галузей, починаючи від прав людини, прав працівників та безпеки праці, питань доступу до інформації, оподаткування та охорони навколишнього середовища. 3 метою поширення та забезпечення дотримання 12 березня 2014 року Рада ОЕСР прийняла рішення щодо поглиблення співпраці з Україною, а 7 жовтня 2014 року у штаб-квартирі ОЕСР у Парижі було підписано Меморандум про взаєморозуміння між Урядом України та ОЕСР щодо поглиблення співробітництва. Після приєднання України до Декларації ОЕСР щодо принципів міжнародного інвестування та діяльності транснаціональних компаній Національний Контактний пункт з'явиться і в Україні.

У липні 2001 року Європейська комісія опублікувала Зелену книгу про корпоративно соціальну відповідальність. У квітні 2003 року Європейський парламент прийняв Резолюцію щодо корпоративної соціальної відповідальності. А в 2011 році було прийнято оновлену стратегію Європейського Союзу по КСВ, яка запрошує уряди всіх країн-членів $Є С$ до розробки національних політик по КСВ та закликає застосовувати щодо компаній мікс добровільності та регуляції в сфері КСВ. Водночас одним із головних принципів оновленої стратегії проголошено публічну звітність компаній, які мають розкривати соціальні і екологічні показники діяльності. Серед міжнародних норм і стандартів, що перераховані в стратегії ЄС щодо КСВ - і Глобальний договір ООН, і 180 26000, і Керівні принципи ОЕСР щодо транснаціональних компаній [5, с. 119].

Стратегія запрошує уряди всіх країн-членів ЄС до розробки національних політик по КСВ, як наслідокна сьогодні майже всі країни-члени ЄС мають національні урядові політики щодо КСВ. Перші кроки України на шляху до створення національної стратегії КСО сталися в 2013 році, коли в червні 2013 року указом Президента затвердилися плани щодо розроблення стратегії сприяння розвитку соціальної відповідальності бізнесу. Над стратегією починала працювати робоча група при Координаційній раді сприяння розвитку громадянського суспільства в Україні. Ї̈̈ робота припинила майже на три роки у зв' язку з ситуацією в країні (анексія Криму, військові дії на Донбасі) та відновлюється у лютому 2016 року. Група фрункціонує у статусі ініціативної в рамках відкритої до приєднання громадянської платформи.

На сучасному етапі розвитку в Україні актуалізується дотримання принципів соціальної відповідальності, що, передусім, викликано підтримкою глобальних ініціатив: Глобального договору Організації Об'єднаних Націй (ГД ООН), Керівництва для мультинаціональних підприємств Організації економічного співробітництва та розвитку (ОЕСР), Всесвітньої ради бізнесу із сталого розвитку (ВС 8Б), Принципів ООН з соціальної відповідальності інвесторів (PКІ), Глобальної ініціативи зі звітності (ОКІ), Міжнародного стандарту 180 26000:2010 "Керівництво з соціальної відповідальності" [11].

Перші кроки на шляху українського бізнесу до соціального підприємництва та соціальної відповідальності бізнесу - це етап корпоративної фрілантропії, коли українські ФПГ створюють благодійні фонди олігархів, які $є$ власниками цих ФПГ. На рішення українських капіталістів рухатися в напрямі соціальної відповідальності бізнесу у той період вплинуло декілька фракторів:

- негативний імідж, що став результатом первинного накопичення капіталу; приватизація деяких об'єктів, умови продажу яких були дискримінаційними (виписаними під певних покупців);

- необхідність подолання негативного сприйняття громадянами ролі великого капіталу в суспільних процесах, необхідність легітимації великого капіталу серед громадян країни, захист приватизованих активів від реприватизації;

- необхідність виходу ФПГ на західні ринки, залучення іноземних інвестицій;

- трансформація соціальних інвестицій у політичний капітал, що міг би бути використаний у період виборів; 
- розуміння того, що успіх бізнесу залежить не лише від фрінансових показників і взаємовідносин з владою, а й від взаємовідносин компанії із суспільством [2, c. 48].

До найгучніших проектів цього напряму слід віднести фонди Віктора Пінчука та Рината Ахметова. Так, фонд Віктора Пінчука фрінансував боротьбу зі СНІДом, працював над створенням центрів допомоги для новонароджених, підтримував талановитих студентів, виплачуючи їм стипендію фундації, реалізовував програму вивчення Голокосту в Україні. Сьогодні фундація Ахметова переважно допомагає переселенцям з тимчасово окупованих територій і населенню, що залишилося на Донбасі.

Одним з найбільш яскравих наочних прикладів, коли соціальна відповідальність великого бізнесу трансорормувалася в політичний капітал, стала діяльність Маріупольського металургійного комбінату ("ММК ім. Ілліча"), головою правління якого з 1997 по 2010 роки був Володимир Бойко (з 2010 по 2012 роки Бойко був гендиректором меткомбінату). "Місто одного бренда" - так мас-медіа на той час називали Маріуполь, в якому комбінат і його підприємства, очолювані Володимиром Бойком, були основним місцем зайнятості населення. Комбінат надавав жителям міста не тільки робочі місця, але і реалізував безліч соціальних програм щодо підтримки пенсіонерів, ветеранів праці, підвищення кваліфікації та оздоровлення персоналу, фрінансував програму з розвитку транспортної інфрраструктури міста. За рахунок засобів комбінату в місті вводилися в експлуатацію об'єкти соціально-культурного і побутового призначення.

За етапом корпоративної фрілантропії, що була характерна для України початку нульових, настає період, коли підприємства починають інтегрувати соціальну відповідальність у корпоративні стратегії. Соціальна відповідальність бізнесу стає новим напрямом діяльності, і в країні з'являються перші фрахівці з корпоративно-соціальної відповідальності - корпоративна соціальна відповідальність стає профресійною сферою.

3 метою впровадження соціальної відповідальності для системних і якісних змін в Україні у 2008 році була заснована Експертна організація Центр "Розвиток корпоративної соціальної відповідальності" (Центр КСВ).

Центр КСВ працює за чотирма пріоритетними напрямами: КСВ у кризові часи, розвиток освіти, соціальна відповідальність державних органів влади і просування України за кордоном. Центр КСВ працює на всій території України з більш ніж 100 компаніями, 200 університетами, 20 школами, 60 державними компаніями i 40 муніципалітетами [12].

Загалом, Центр реалізував понад 80 проектів, підготував та видав більше 135 публікацій, провів більше 250 публічних заходів, в яких взяли участь близько 4500 представників бізнесу, громадських організацій та засобів масової інформації.

У 2018 році Центр "Розвиток КСВ" презентував дослідження щодо того, як українські компанії впроваджують Цілі сталого розвитку. Партнер дослідження Платформа зростання зеленої економіки.

Наприкінці 2000-х відбулося відокремлення благодійності від корпоративної соціальної відповідальності: особисті благодійні фронди олігархів стали самостійними суб'єктами, що функціонували окремо від активів олігархів, а активи почали працювати за власною програмою корпоративної соціальної відповідальності, яка поступово ставала частиною стратегічного менеджменту. Саме в цей період бізнес уперше звернувся до практик по збереження навколишнього середовища: відбувся перший український бізнес- саміт з питань зміни клімату, в портфоліо українських компаній з'явився КСВ-кейси з охорони довкілля ("Тетра ПАК", "Прикарпаттяобленерго", "Астарта", ДГОК, "Галнафтогаз", "Київстар" та інші). На цьому ж етапі одним із напрямів корпоративної соціальної відповідальністі стають освітні програми [10, с. 74].

"Київстар" зосередився на проекті допомоги дітям з обмеженими можливостями: компанія у 2010 році обладнала мультимедійні класи у восьми інтернатах для дітей, які не бачать. За допомогою комп'ютерної техніки, спеціального програмного забезпечення, доступу в Інтернет і безкоштовного трафріку діти отримали нові можливості для розвитку і освіти.

Розрив між якістю освіти та вимогами роботодавців спричинив появу двох освітніх проектів, які реалізовувалися за підтримки Міносвіти.

Перший з них - Міжкорпоративний університет, що стартував у 2009 році. Українські компанії та провідні виші ("МТС Україна", "МЕTPO Кеш енд Керрі Україна", "Київська інвестиційна група", Київський національний університет імені Т. Шевченка, Національний технічний університет України "Київський політехнічний інститут", Національний університет "Києво-Могилянськ академія") об'єднали зусилля в проекті Міжкорпоративний університет. Ця програма стала першим в Україні партнерським проектом у галузі освіти, який передбачав інтеграцію практичних знань і досвіду компаній у процес підготовки майбутніх фахівців. Студенти, які здобували освіту в стінах університету, надбали саме тих навичок та знань, які затребувані в бізнес-практиках.

Другий проект - "паспорт професії", що був започаткований СКМ у 2011 році. Компанія ініціювала проект з розробки сучасних професійних стандартів, які мали на меті допомогти скоротити дисбаланс на ринку праці між попитом і пропозицією фрахівців. У профстандартах чітко прописано, що повинен знати і вміти фрахівець, щоб відповідати сучасним вимогам ринку [7, c. 391].

Події з кінця 2013 року - Революція Гідності, анексія Росією Криму, утворення самопроголошених "ЛНР" i "ДНР", гібридна війна і тероризм на Сході України не лише згуртували суспільство, дестабілізували економіку країни, а й суттєво змінили напрям соціальних проектів значної частини бізнесу. Одним із мотивів суспільної відповідальності українських бізнесменів стає громадянська відповідальність. Жоден з міжнародних стандартів корпоративної соціальної відповідальності не містить пункту про захист власної країни в період військових дій. Жодна зі стратегій КСВ в Україні не мала пункту про допомогу армії військовим, пораненим чи вимушеним переселенцям.

Велике значення для імплементації соціальної відповідальності в Україні має представлена 15 вересня 2017 року Урядом Національна доповідь "Цілі ста- 
лого розвитку: Україна", яка визначає базові показники для досягнення Цілей сталого розвитку. Глобальні Цілі сталого розвитку були затверджені у 2015 році на саміті ООН з питань сталого розвитку. За ініціативи Уряду України та за сприяння ООН в Україні протягом року тривав відкритий та інклюзивний процес адаптації ЦСР. Беручи до уваги принцип "нікого не залишити осторонь" та використовуючи широкий спектр інформаційних, статистичних та аналітичних матеріалів, була розроблена національна система ЦСР (86 завдань розвитку та 172 показники для моніторингу їх виконання).

У доповіді представлені результати адаптації 17 глобальних ЦСР з урахуванням специфіки національного розвитку.

Зовнішні обставини відкорегували спрямування благодійних бюджетів великого бізнесу, а для малого і середнього - стали мотивом, який спонукав багато підприємств уперше приєднатися до суспільно корисних дій.

Український бізнес бере найактивнішу участь у волонтерському русі, поєднавши свої дії з волонтерськими організаціями, а також реалізує безліч власних проектів, допомагаючи армії чи вимушеним переселенцям. Сьогодні українські компанії зберігають робочі місця за мобілізованими співробітниками, придбають необхідне військове спорядження; організовують переїзд та частково компенсують вартість житла співробітникам, що опинилися на території конфрлікту; відтворюють інфрраструктуру та соціальні об'єкти в регіонах, що постраждали від військових дій.

Проблеми зайнятості вимушених переселенців допомогає вирішити ДТЕК. Компанії "Фокстрот", "Астеліт", "Василь Кісіль і партнери" опікуються дітками із зони АТО. Допомога армії стала напрямом діяльності "Концерну Галнафтогаз", "Приватбанку", "Агота", "Кііо", "Оболоні", "Фармак", "Здоров'я", "Нової Пошти" та багатьох інших. Серед кейсів цього періоду - допомога армії власною продукцією, перерахування власного заробітку чи відсотка від продажу, участь у зборі коштів [2, с. 49].

Ініціативи компаній були найрізноманітнішими:

- одна із ініціатив "Приватбанку" - спільний проект з оператором мобільного зв'язку PEOPLEnet. Компанії запросили українців приєднатися до благодійної ініціативи та передати непотрібні СБМА телефони українським воїнам у зоні АТО: телефони приймалися в будь-якому з відділень "Приватбанку" по всій Україні, PEOPLEnet встановлював на такі апарати безкоштовний зв'язок всередині своєї мережі і відправляв українським воїнам у зону АТО;

- "Новапошта" організувала соціальну ініціативу "Гуманітарна пошта України", яка дає можливість волонтерським організаціям та ініціативним групам відправляти і отримувати гуманітарні вантажі безкоштовно в будь-якому відділенні компанії по всій Україні. У програмі беруть участь волонтерські організації та ініціативні групи, які систематично на постійній основі займаються збором і доставкою різної гуманітарної допомоги:солдатам української армії, які проходять службу в зоні АТО, пораненим солдатам української армії по всій країні, жителям постраждалих регіонів, вимушеним переселенцям зі Сходу України;
- сервіс виклику таксі Uklon проводить акції "Військове таксі", мета яких - збір коштів на авто для української армії. У дні акцій сервіс перераховує всю вартість поїздки на купівлю авто військовослужбовцям.

Балансуючи між економічною раціональністю та суспільною відповідальністю, український бізнес пройшов довгий шлях, результати якого досить неочікувані. Ми стали свідками появи унікальної моделі коорпоративно-соцільної відповідальності, яка базується не лише (і навіть не стільки) на міжнародних принципах і стандартах, а передусім на відповідальності за захист власної держави.

Серед найбільш затребуваних орієнтирів соціального підприємництва періоду 2014-2017 років слід назвати такі:

- трудові практики (релокація співробітників та їх сімей на безпечні території, збереження робочого місця за мобілізованими співробітниками, збір коштів для придбання необхідного військового спорядження для мобілізованих, допомога пораненим співробітникам, сім'ям загиблих, організація заходів, спрямованих на боротьбу зі стресом);

- інвестиції у території присутності компаній (відновлення інфраструктури звільнених населених пунктів, гуманітарна допомога цивільному населенню, освітні проекти для дітей, допомога вимушеним переселенцям, допомога сім'ям загиблих, психологічна реабілітація військових);

- інвестиції у обороноздатність країни (допомога армії, інфрормаційна робота);

- інтелектуальні інвестиції в ході реформування країни (консультування органів влади, надання органам влади результатів власних досліджень) [12].

\section{ВИСНОВОК}

У процесі еволюції концепції соціально відповідального бізнесу науковцями сорормована ціла система поглядів, суджень, теоретичних конструкцій, які хоч і доволі різняться, проте не суперечать, а скоріше доповнюють одна одну та вступають у ролі своєрідних етапів розвитку явища.

Соціальна відповідальність бізнесу - складна філософська, інтегрувальна морально-етична, правова, соціально-економічна, управлінська категорія, яка під різними кутами зору й у різних площинах подана в низці теоретико-прикладних розробок.

Найбільш повним, на нашу думку, є визначення соціальної відповідальності бізнесу як сукупності зобов'язань, які добровільно бере на себе компанія з урахуванням думок працівників, акціонерів, представників місцевих громад та інших ключових зацікавлених осіб.

У такому контексті соціально відповідальний бізнес виступає важливим чинником зростання соціальної згуртованості. Відповідно, від впровадження соціальновідповідальних ініціатив окремих організацій значні переваги отримують усі члени суспільства. Зокрема слід назвати такі соціально значимі результати впровадження соціально відповідального бізнесу на загальнонаціональному рівні: зростання рівня добробуту та якості життя населення; підвищення конкурентоспроможності 
національної економіки; зменшення навантаження на місцеві бюджети за рахунок добровільних соціальних ініціатив бізнесу; оптимізація механізмів захисту прав власності та корпоративного управління; розвиток програм екозбереження та економії ресурсів; детінізація бізнесу та зниження рівня корумпованості суспільства; подолання соціальної ізольованості та зниження рівня соціальної конфліктності за рахунок налагодження взаємодії різних суспільних суб'єктів через соціальний діалог; удосконалення існуючих та розвиток нових форм соціального та державно-приватного партнерства.

\section{Література:}

1. Абрамов Р.Н. Корпоративная социальная ответственность как пример организационного изоморфизма в условиях глобализации. Журнал исследований социальной политики. 2005. Т. 3. № 3. С. 327-346.

2. Бержанір А.Л., Чирва Г.М. Методологія теоретичних досліджень корпоративної соціальної відповідальності. Глобальні та національні проблеми економіки. № 2018. Випуск 21. С. 45-49.

3. Гончаров С.Ф. Корпоративная социальная ответственность в системе социальной защиты занятого населения: диссер. к. э. н. Специальность 08.00.10 [текст]. М.: 2011.53 c.

4. Данилова О.В. Социальная ответственность бизнеса в системе рыночного хозяйства (теоретико-экономический аспект): автореферат диссер. д. э. н. Специальность 08.00.01 [текст]. М.: 2012. 42 с.

5. Клименко І.М. Теоретико-методологічний підхід до ролі соціальної відповідальності бізнесу в сучасних умовах. Інвестиції: практика та досвід. 2018. № 8. С. 118-125.

6. Колот А.М. Корпоративна соціальна відповідальність: еволюція та розвиток теоретичних поглядів. Економічна теорія. 2013. № 4. С. 5-26.

7. Матвієнко-Біляєва Г.Л. Розвиток та становлення соціального підприємництва та соціальної відповідальності в сучасних умовах. Економіка і суспільство. 2016. № 7. С. $390-394$.

8. Перегудов С.П. Корпоративное гражданство как современная форма социальной инженерии. Мировая экономика и международные отношения. 2005. № 96. С. 22-32.

9. Сотула О. В. Соціальне підприємництво як інноваційна модель розвитку економіки. Ефективна економіка. 2013. № 4. С. $67-70$.

10. Шутаєва О.О. Соціальна відповідальність в досягненні конкурентоспроможності підприємства. Культура народов Причерноморья. 2014. № 273. С. 73-78.

11. Карпенко О.О., Мандзюк Н.К. Соціальна відповідальність як чинник економічного розвитку вітчизняних підприємств. Електронне наукове фахове видання "Ефективна економіка". 2018. № 4. URL: http:// www.economy.na yka.com. ua/pdf/4_2018/7.pdf

12. Сайт ЦВК URL: http://www.cvk. gov.ua/pls/ vnd $2007 /$ w6p001

13. Carroll A. B. A three-dimensional conceptual model of corporate. Academy of Management Review. 1979. Vol. 4 (4). P. 500.

14. Frederick W. C. From CSR-1 to CSR-2: the maturing of business-and-society thought. 1994. P. 154-155.
15. Swanson D.L. Addressing a theoretical problem by reorienting the corporate social performance model. Academy of Management Reviewю. 1995. 20 (1). P. 4364.

\section{References:}

1. Abramov, R.N. (2005), "Corporate social responsibility as an example of organizational isomorphism in the context of globalization", Zhurnal issledovanij social'noj politiki, vol. 3, pp. $327-346$.

2. Berzhanir, A.L. and Chyrva, H.M. (2018), "Methodology of theoretical studies of corporate social responsibility", Hlobal'ni ta natsional'ni problemy ekonomiky, vol. 21 , pp. $45-49$.

3. Goncharov, S.F. (2011), "Corporate social responsibility in the system of social protection of the employed population", Abstract of Ph.D. dissertation, Global economy, Russian State Social University, Moscow, Russia.

4. Danilova, O.V. (2012), "The social responsibility of business in the system of market economy (the theoretical and economic aspect) ", Abstract of Dr. dissertation, Global economy, Moscow, Russia.

5. Klymenko, I.M. (2018), "Theoretical and methodological approach to the role of social responsibility of business in modern conditions", Investytsii: praktyka ta dosvid, vol. 8, pp. 118-125.

6. Kolot, A.M. (2013), "Corporate Social Responsibility: The Evolution and Development of Theoretical Views", Ekonomichna teoriia, vol. 4, pp. 5-26.

7. Matviienko-Biliaieva, H.L. (2016), "Development and incipience of social entrepreneurship and social responsibility in modern conditions", Ekonomika i suspil'stvo, vol. 7, pp. 390-394.

8. Peregudov, S.P. (2005), "Corporate citizenship as a modern form of social engineering", Mirovaja jekonomika i mezhdunarodnye otnoshenija, vol. 96, pp. 22-32.

9. Sotula, O.V. (2013), "Social entrepreneurship as an innovative model of economic development", Efektyvna ekonomika, vol. 4, pp. 67-70.

10. Shutaieva, O.O. (2014), "Social responsibility in achieving competitiveness of the enterprise", Kul'tura narodov Prychernomor'ia, vol. 273, pp. 73-78.

11. Karpenko, O.O. and Mandziuk, N.K. (2018), "Social responsibility as a factor of economic development of domestic enterprises:, Efektyvna ekonomika, [Online], vol. 4, available at: http:/ / www.economy.nayka.com.ua/pdf / 4_2018/7.pdf (Accessed 25 Oct 2019).

12. The official site of Centre Corporate Social Responsibility Development (2019), "About CSR Ukraine", available at: http:/ /csr-ua.info/pro-centr-ksv (Accessed 25 Oct 2019).

13. Carroll, A.B. (1979), "A three-dimensional conceptual model of corporate", Academy of Management Review, vol. 4, p. 500.

14. Frederick, W.C. (1994), "From CSR-1 to CSR-2: the maturing of business-and-society thought", Business and society, vol. 33(2), p. 150-164.

15. Swanson, D.L. (1995), "Addressing a theoretical problem by reorienting the corporate social performance model", Academy of Management Review, vol. 20, p. 43-64. Стаття надійшла до редакцї̈04.11.2019p. 